\title{
THE EFFECT OF PARTICLE SIZE ON THE CHARACTERIZATION OF ACTIVATED CARBON FROM TROPICAL BLACK BAMBOO (Gigantochloa atroviolacea)
}

\author{
Envrinda Arief Fauzia ${ }^{1}$, Herry Purnama ${ }^{2 *}$ \\ 1,2Program Studi S1 Teknik Kimia, Universitas Muhammadiyah Surakarta \\ Fakultas Teknik, Universitas Muhammadiyah Surakarta
}

\section{Paper Information}

Send, April 21 2021

Revision, Juni $04^{\text {th }} 2021$

Accept, May $31^{\text {st }} 2021$

\section{Keyword:}

Activated carbon

Bamboo waste

Carbonation

Activation

Phosphoric acid

\section{Kata Kunci:}

Karbon aktif

Limbah bambu

Karbonasi

Aktivasi

Asam Fosfat

\begin{abstract}
Activated carbon also known as activated charcoal is a common term for carbon materials, which comprises charcoal. Activated carbon has a good adsorption capacity against gases and pollutants in liquids because of its wide surface. The material used in this research was tropical black bamboo, with the variation of particle size -10+20 mesh, -20+40 mesh, -40+60 mesh and -60+80 mesh. There are 2 processes to produce activated carbon, i.e. carbonation and activation. In this research, the carbonation is set at $380^{\circ} \mathrm{C}$ in 1 hour. Then, each size of carbon was activated by $\mathrm{H}_{3} \mathrm{PO}_{4} 9.8 \%$ along 24 hours. The analysis conducted were moisture content, ash content, iodine number, and functional group analysis using Fourier Transform Infrared Spectroscopy (FTIR). The smaller particle size, the more pores will be produced and it caused the surface area higher. The results showed that variation of particle size had effect on the characterization and quality of activated carbon, where moisture content is between 10.60 to $4.05 \%$, ash content is $1 \%$ to $0.2 \%$ and iodine adsorption is between $710 \mathrm{mg} / \mathrm{g}$ to $900 \mathrm{mg} / \mathrm{g}$. In FTIR analysis, it showed that all of the samples had $\mathrm{O}-\mathrm{H}, \mathrm{C}=\mathrm{C}$, and $\mathrm{C}-\mathrm{O}$ functional group.
\end{abstract}

\section{INTISARI}

Karbon aktif atau disebut juga arang aktif adalah istilah umum untuk bahan karbon, yang terdiri dari arang. Karbon aktif memiliki kapasitas adsorpsi yang baik terhadap gas dan polutan dalam cairan karena permukaannya yang luas. Material yang digunakan dalam penelitian ini adalah limbah bambu wulung yang berasal dari industri kerajinan tirai bambu. Variasi ukuran partikel pada penelitian ini adalah $-10+20$ mesh, -20+40 mesh, -40+60 mesh, dan -60+80 mesh. Terdapat 2 proses untuk menghasilkan karbon aktif, yaitu karbonasi dan aktivasi. Pada penelitian ini karbonasi diatur pada suhu $380^{\circ} \mathrm{C}$ selama satu jam. Kemudian masing-masing ukuran karbon diaktivasi dengan $\mathrm{H}_{3} \mathrm{PO}_{4} 9,8 \%$ selama 24 jam. Analisis yang dilakukan adalah analisis kadar air, kadar abu, daya serap iodin, dan analisis gugus fungsi menggunakan Fourirer Transform Infrared Spectroscopy (FTIR). Semakin kecil ukuran partikel maka akan semakin banyak pori yang dihasilkan dan menyebabkan luas permukaan semakin tinggi. Hasil penelitian menunjukkan bahwa variasi ukuran partikel berpengaruh terhadap karakterisasi dan kualitas karbon aktif, dimana kadar air antara 10,60-4,05\%, kadar abu $1 \%$ - 0,2\% dan adsorpsi bilangan iodium antara $710 \mathrm{mg} / \mathrm{g}$ sampai $900 \mathrm{mg} / \mathrm{g}$. Hasil analisis FTIR menunjukkan bahwa semua sampel memiliki gugus fungsi $\mathrm{O}-\mathrm{H}, \mathrm{C}=\mathrm{C}$, dan $\mathrm{C}-\mathrm{O}$.

\section{Author Correspondence:}

\author{
Herry Purnama \\ Program Studi Teknik Kimia \\ Universitas Muhammadiyah Surakarta \\ Jl. Ahmad Yani, Pabelan, Kartasura, Tromol Surakarta 57162 \\ Email: hp269@ums.ac.id
}




\section{INTRODUCTION}

Activated carbon is an amorphous compound produced from materials containing high carbon, through a carbonation process. Activated carbon has a good adsorption capacity for gases and pollutants in liquids because of its wide surface. Activated carbon is currently very intensively used as an adsorbent, because of its high adsorption capacity and is thermally stable and easy to obtain. The raw materials of activated carbon production is from agricultural waste, coal, coconut shells, bamboo, and others [1]. Activated carbon contains hydrogen and oxygen which are attached to functional groups such as carboxyls, phenols, and ethers [2]. The fine structure of activated carbon increased the surface area $\left(>1000 \mathrm{~m}^{2} / \mathrm{g}\right)$ of pores that make it has high adsorptive properties. Activated carbons are applied in various shapes, suchas powder, granular, pellet, honeycomb and activated carbon fiber (ACF), and each type has its specific application [3]. Activated carbon also becomes important filter material for the removal of hazardous components in exhaust gases for the purification of drinking water and for wastewater treatment [4,5]. Carbon as adsorbent can absorb colours and odours because the contaminants and/or pollutants are bound to the active and free sites on the carbon surface until it is filled up [6].

As a type of natural plant material, bamboo is a potential renewable biomass with the advantages of fast growth and high yield. Bamboo charcoal is a new porous material with high porosity and a special micropore structure, which bamboo can obtain in high temperature and anoxic conditions. [7].Bamboo grows fast and can be harvested every four years. Replacing wood with bamboo for the preparation of porous charcoal can reduce carbon dioxide emissions.[8]

Carbonation and activation are the process to produce activated carbon. Carbonation process aims to evaporate volatile substances, so they can open the pores of the activated carbon surface. Carbonation occurs with several stage which includes the removal of water or dehydration, a change in ingredient organics into carbon elements and tar decomposition resulting in pores carbon gets biggerThe purpose of the activation process is to increase or enlarge the pores diameter of carbon and expand the volume absorbed in the pore and to open new pores [9].

The activated carbon with good quality should comply with quality standard of activated carbon according to SNI 06-3730-1995 about standard quality and activated carbon tesing, that shows in the Table 1.

Table 1. Standard of Activated Carbon SNI 06-3730-1995

\begin{tabular}{l|l}
\hline Type of testing & Parameter \\
\hline Moisture content & Max .15\% \\
Ash content & Max. $10 \%$ \\
Iodine absorption & Min. $750 \mathrm{mg} / \mathrm{g}$ \\
\hline
\end{tabular}

The relevant research was done, and produced activated carbon from string bamboo (Gigantochloa apus) using $\mathrm{H}_{3} \mathrm{PO}_{4}$ as activator with the variation of activator concentration, time and temperature. The result of this research was the bamboo can be made into activated charcoal with an activator $\mathrm{H}_{3} \mathrm{PO}_{4}$. Another research showed iodine absorption increased by the mesh size. From the size $-20+40$ mesh; $-40+60 ;-60+80 ;-80+100$ mesh resulted iodine adsorption by the number $228.42 ; 304.56 ; 507.60 ; 710.64 \mathrm{mg} / \mathrm{g}[10,11]$.

To reduce the amount of bamboo waste from handycraft industry, it requires processing bamboo waste into valuable products such as activated carbon. Based on the background, this research aims to know the effect of particle size on the characterization of activated carbon from bamboo waste using activator $9.8 \% \mathrm{H}_{3} \mathrm{PO}_{4}$. The main material is tropical black bamboo, or wulung in Indonesia, as bamboo waste from traditional curtain industry.

\section{METHODS}

The materials used in this research are bamboo waste, aquadest, $1 \%$ amylum or starch, $9.8 \% \mathrm{H}_{3} \mathrm{PO}_{4}$, Iodine $0.1 \mathrm{M}$ and $\mathrm{Na}_{2} \mathrm{~S}_{2} \mathrm{O}_{3}$ 0.1 M. And the tools for this research are screen (size 10+20 mesh, -20+40 mesh, 40+60 mesh and -60+80 mesh), hotplate magnetic stirrer, oven, furnace, desicator, beaker glass, erlenmenyer, analythical balance.

There were the steps how the research conducted:

1. Sample preparation from bamboo waste

The sample are cut in $\pm 2 \mathrm{~cm}$. Then wash with water and dry it at temperature $100^{\circ} \mathrm{C}$ until the weight is constant. 
2. Carbonation

Then sample is dried at temperature $380^{\circ} \mathrm{C}$ around one hour using the furnace. The carbon formed then grind using mortar and sieve in various size of screen size 10+20 mesh, -20+40 mesh, -40+60 mesh and $-60+80$ mesh.

3. Activation

In activation step, solve 20 grams of each size of particles in the activator solution in beaker glass. The solution is $9.8 \% \mathrm{H}_{3} \mathrm{PO}_{4}$ in $100 \mathrm{ml}$ aquadest. Then carbonized charcoal was activated by immersing it for 24 hours. The yield of carbon is filtered and rinsed with distilled water until the $\mathrm{pH}$ is neutral, then put it in an oven with a temperature of $100^{\circ} \mathrm{C}$ for an hour. The result is cooled in decicator to room temperature.

4. Analysis

1. Water Content

Weighed 1 gram of sample in a porcelain cup and then put it in the oven at $110^{\circ} \mathrm{C}$ until a constant weight is obtained. Water content is calculated by the following equation:

$$
\begin{aligned}
& \% \mathrm{WC}=\frac{a-b}{a} \times 100 \% . \\
& \text { a: initial mass } \\
& \text { b: mass after drying }
\end{aligned}
$$

2. Ash Content

1 gram of sample in porcelain cup is heated in a furnace at $650{ }^{\circ} \mathrm{C}$ for 2.5 hours, until ash is formed, cooled in a desiccator, weighed.

$$
\% \text { Ash }=\frac{\text { mass of ash }}{\text { mass of carbon }} \times 100 \%
$$

3. Iodine Adsorption

Weighed 0.5 grams of charcoal and then put it in the erlenmeyer, added $20 \mathrm{~mL}$ of $0.10 \mathrm{~N}$ iodine solution, stirred for 15 minutes at room temperature. Then the mixture is centrifuged until two layers are formed. $8 \mathrm{~mL}$ of supernatant pipette, put into Erlenmeyer. The solution is titrated with sodium thiosulfate solution using the starch indicator $1 \%$, until the blue color disappears.

4. Functional Group Analysis

The functional groups of activated carbon were determined using FTIR method, conducted in Laboratorium Terpadu UII. The spectrum results are then compared with literature.

\section{RESULT AND DISCUSSION}

\subsection{Result}

Based on the characterization of activated carbon as adsorbent from bamboo waste by the variation of particle size are -10+20 mesh (F1), -20+40 mesh (F2), -40+60 mesh (F3), -60+80 mesh (F4) with activator $9.8 \% \mathrm{H}_{3} \mathrm{PO}_{4}$, the activated carbon that formed is powder and black. Then the activated carbon has been analyzed by moisture content, ash content, iodine number and FTIR. The following table shows the result of the analysis:

Table 2. Data of moisture content, ash content and iodine number

\begin{tabular}{lcccc}
\hline \multicolumn{1}{c}{ Parameter } & Sample F1 & Sample F2 & Sample F3 & Sample F4 \\
\hline Moisture content & $10.60 \%$ & $9.34 \%$ & $7.16 \%$ & $4.05 \%$ \\
Ash content & $1.0 \%$ & $0.9 \%$ & $0.8 \%$ & $0.2 \%$ \\
Iodine number (mg/g) & 710.64 & 808.98 & 837.54 & 900.99 \\
\hline
\end{tabular}

Table 3. Data of FTIR analysis of each sample

\begin{tabular}{cccc}
\hline & Wavenumber $\left(\mathrm{cm}^{-1}\right)$ & Functional group & Intensity \\
\hline \multirow{2}{*}{ F1 } & 3466.69 & O-H & 13.682 \\
& 1595.57 & $\mathrm{C}=\mathrm{C}$ & 23.657 \\
& 1229.26 & $\mathrm{C}-\mathrm{O}$ & 27.151 \\
\hline \multirow{2}{*}{ F2 } & 3425.41 & O-H & 28.707 \\
& 1596.85 & $\mathrm{C}=\mathrm{C}$ & 39.317
\end{tabular}




\begin{tabular}{cccc} 
& 1217.30 & $\mathrm{C}-\mathrm{O}$ & 41.926 \\
\hline \multirow{3}{*}{ F3 } & 3439.37 & $\mathrm{O}-\mathrm{H}$ & 39.717 \\
& 1598.91 & $\mathrm{C}=\mathrm{C}$ & 50.335 \\
& 1171.48 & $\mathrm{C}-\mathrm{O}$ & 52.454 \\
\hline \multirow{2}{*}{$\mathrm{F} 4$} & 3445.57 & $\mathrm{O}-\mathrm{H}$ & 39.599 \\
& 1598.81 & $\mathrm{C}=\mathrm{C}$ & 49.418 \\
& 1171.76 & $\mathrm{C}-\mathrm{O}$ & 51.204 \\
\hline
\end{tabular}

\subsection{Discussion}

\subsubsection{Moisture and Ash Content}

Calculation of moisture content aims to determine the hygroscopic properties of activated carbon, where generally activated carbon has a very large affinity for water. This very hygroscopic property causes the activated carbon can be used as adsorbent [12].

The moisture content analysed by heating the activated carbon at $110^{\circ} \mathrm{C}$. Based on the result in Figure 1, the moisture content is decline following the particle size. When the particle size is small, it will produce small pores that cause the surface area higher. When the number of pores increases, the easier it is to dry. The sequence result of moisture content is $10.60 \%, 9.34 \%, 7.14 \%$ and $4.05 \%$. All the percent moisture is under the maximum value of SNI, that is $15 \%$. This result is related to the research with the variation of particle size is 100 mesh, 140 mesh and 200 mesh and produce moisture content $1.4 \%, 1.27 \%$ and $1.1 \%$ [13].

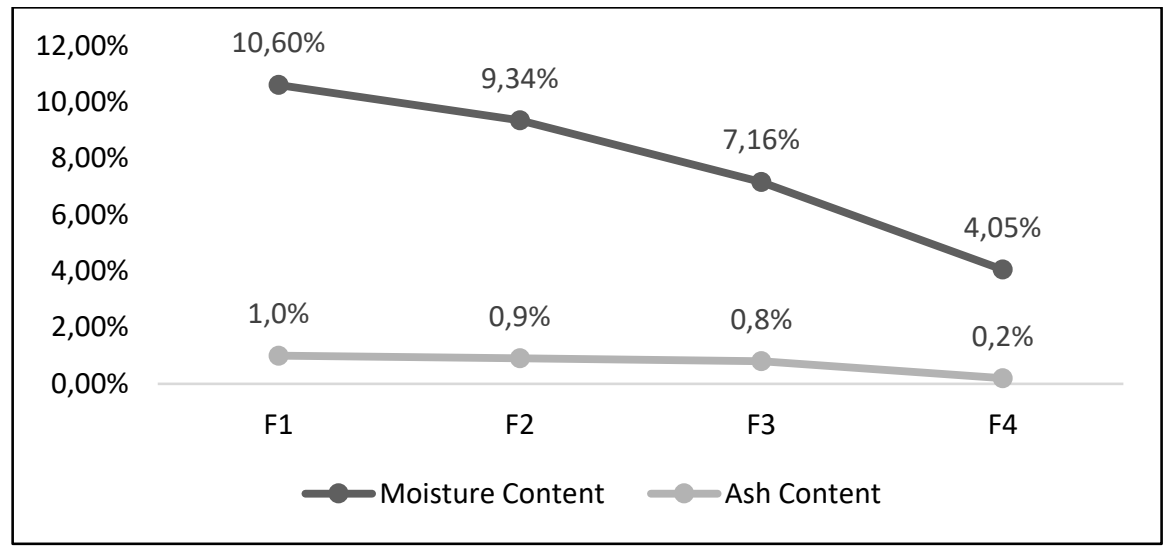

Figure 1. Moisture and ash content as a function of particle size

The analysis of ash content done by heating the activated carbon in furnace at $650^{\circ} \mathrm{C}$ for 2.5 hours. The result obtained based on the variation of particle size is $1 \%, 0.9 \%, 0.8 \%$ and $0.2 \%$, respectively. When the particle size is smaller, it will produce less ash. It means that the particles with smaller sizes when heated to $650^{\circ} \mathrm{C}$ allow these particles to change phase into gas so the amount of ash becomes less. All the sample has low ash content, where the maximum value of ash content from $\mathrm{SNI}$ is $10 \%$. Low ash content indicates that mineral oxides such as $\mathrm{Na}, \mathrm{K}, \mathrm{Mg}$ and $\mathrm{Ca}$ are left in very little amount of activated carbon. The presence of excess ash can cause blockage of activated carbon, so the carbon surface becomes less [13,14].

\subsubsection{Iodine Number Adsorption}

The purpose of this analysis is to determine the adsorption ability of activated carbon in coloured solution. The sample was analysed by iodometric method where the iodine number obtained will show the ability of its adsorption power. The efficiency of the adsorption process depends on the physicochemical characteristics of the adsorbate and adsorbent. For the latter, factors such as the pore size, area, and surface chemistry are relevant if the process is carried out in activated carbon. Adsorption capacity also depends on the characteristics of the activated carbon such as carbon content, ash content, moisture content, surface area and the yield. The main factor that greatly influences the adsorption power is the surface area of activated carbon because the adsorption mechanism is related to the number of pores $[15,16]$. 


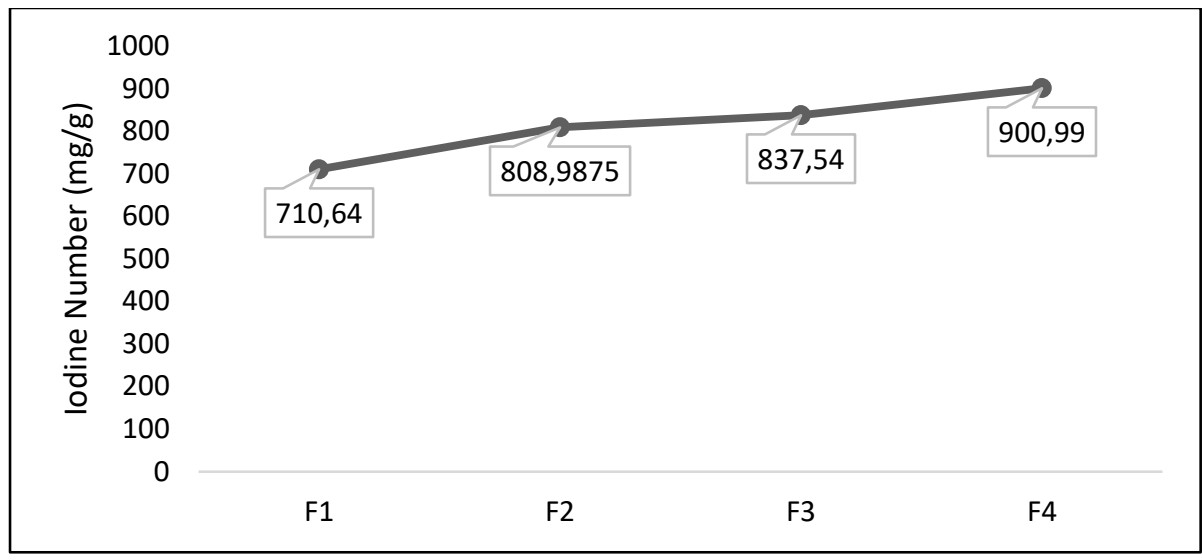

Figure 2. Iodine number adsorption as a function of particle size

From the result of this study, the iodine number increase by the smaller size of particle. The best iodine number is $900.99 \mathrm{mg} / \mathrm{g}$ from sample $\mathrm{F} 4$, with the size of particle is $-60+80$ mesh or 0.25 $0.177 \mathrm{~mm}$. From 4 samples, sample F1 is $710.64 \mathrm{mg} / \mathrm{g}$, which is not achieved to SNI where the minimal iodine value is $750 \mathrm{mg} / \mathrm{g}$. The higher the mesh value, the more pores of activated carbon open and forming a cavity that is bigger in size than the iodine molecule so that the iodine molecule enters the activated carbon [17].

\subsubsection{Functional Group Analysis}

The functional groups contained in activated carbon from black bamboo can be determined by FTIR Spectrophotometer. The analysis conducted on activated samples using $9.8 \% \mathrm{H}_{3} \mathrm{PO}_{4}$. It was carried out from wave numbers $4000-400 \mathrm{~cm}^{-1}$, where in the range of wave numbers there are functional groups and fingerprints that are owned by activated carbon. The results of FTIR spectra for each sample are shown in the Figure 3.

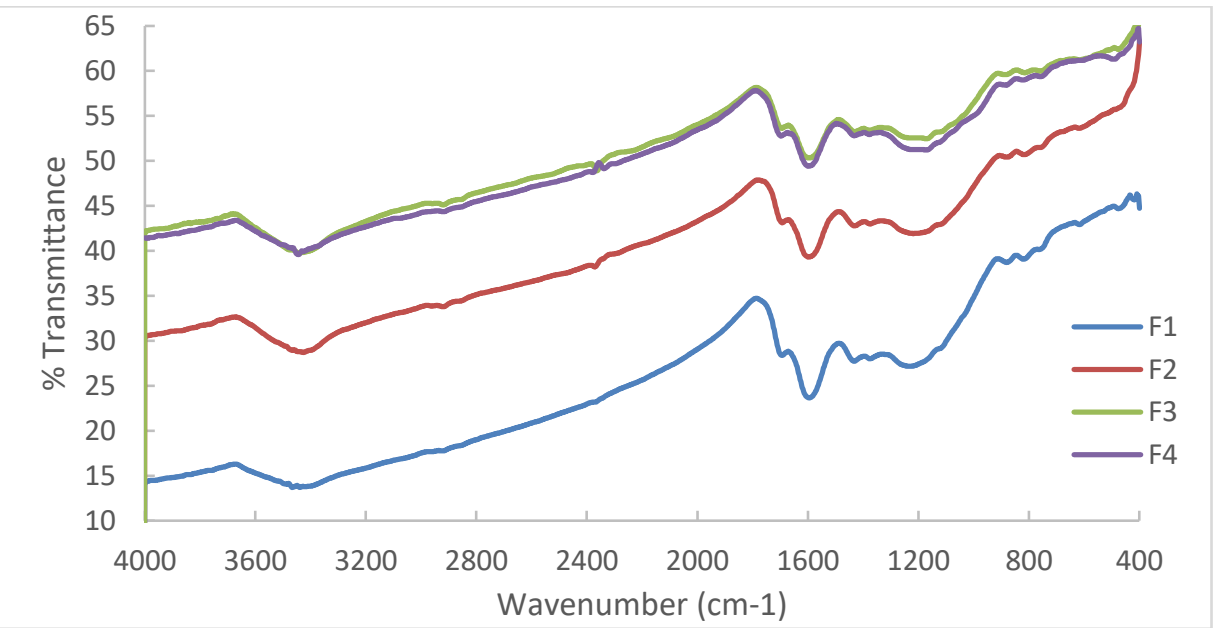

Figure 3. Spectra of FTIR analyis in bamboo activated carbon

The result analysis using FTIR showed that there were peaks appeared. Based on the wavenumber detected, all the sample are dominated with $\mathrm{O}-\mathrm{H}, \mathrm{C}=\mathrm{C}$ and $\mathrm{C}-\mathrm{O}$ group. The result was $\mathrm{d}$ interpret from FTIR Spectroscope of Organic Material [18]. It is proved by the absorption peaks at 3466.69 (F1), $3425.41(\mathrm{~F} 2), 3439.37(\mathrm{~F} 3)$, and $3445.57(\mathrm{~F} 4)$ for O-H stretching where the number $3500-3200 \mathrm{~cm}^{-1}$ refer to hydroxyl group. The decrease in the absorption peak stated in the results occurs due to the decomposition of the adsorbed hydroxyl groups and water. The amount of hydroxyl groups showed a strong hydrogen bond (from carboxyl, phenol or alcohol). For wavenumber 16151450 , it indicates $\mathrm{C}=\mathrm{C}$ group (aromatic ring stretch). As showed in the figure there are absorption peaks at $1595.57(\mathrm{~F} 1), 1596.85(\mathrm{~F} 2), 1598.91(\mathrm{~F} 3)$ and $1598.81(\mathrm{~F} 4)$. And the fact that showed there is C-O group or phenol is absorption peaks at $1229.26(\mathrm{~F} 1), 1217.30(\mathrm{~F} 2), 1171.48(\mathrm{~F} 3)$ and 1171.76 (F4). 
The presence of $\mathrm{O}-\mathrm{H}$ and $\mathrm{C}-\mathrm{O}$ bonds indicates that the activated carbon produced tends to be more polar. Thus, the activated carbon produced can be used as adsorbent in polar substances, tend to purify water, sugar, alcohol, or as an absorber of formaldehyde emissions [19]. Other application show that the use of activated bamboo charcoal as an adsorbent medium can reduce manganese and nitrate ions in water. The results of the study were the optimum adsorption of nitrate is $74.57 \%$ and manganese ion is $60.60 \%$ [20].

\section{CONCLUSION}

The waste of tropical black bamboo can be used as a prospective material in the preparation of activated carbon. This study showed that the phosphoric acid developed and increased the physical properties of activated carbon prepared from black bamboo. Based on the result analysis, it can be concluded that the variation of particle size affected the characterization and quality of activated carbon. Activated carbon with screen size $60+80$ mesh has the best quality between the other samples with low moisture content and ash content at $4.05 \%$ and $0.2 \%$ respectively. It also has high adsorption ability on iodine solution $900.99 \mathrm{mg} / \mathrm{g}$. Activated carbon from bamboo consists of $\mathrm{O}-\mathrm{H}, \mathrm{C}-\mathrm{O}$, and $\mathrm{C}=\mathrm{C}$ functional groups. The two oxygen-containing functional groups are responsible for the decreasing of polar substances in water and the application of this activated carbon can be expanded in future study. In example, application in purifying water or reducing hazardous metal content in waste water. This study also can be used as reference to the next study by adding the variation of time activation, so the best activation time will be known.

\section{REFERENCES}

[1] Hesas RH, Arami-Niya A, Wan Daud WMA, Sahu JN. "Preparation and Characterization of Activated Carbon from Apple Waste by Microwave-Assisted Phosphoric Acid Activation: Application in Methylene Blue Adsorption." BioResources. 2013. 8(2):2950-66.

[2] Anggraini PD. "Pengolahan Limbah Cair Industri Tekstil Batik dengan Menggunakan Metode Fotokatalis Tio2 Karbon Aktif Tempurung Kelapa" Politeknik Perkapalan Negeri Surabaya. 2019.

[3] Saeidi N, Lotfollahi MN. "Effects of Powder Activated Carbon Particle Size on Adsorption Capacity and Mechanical Properties of the Semi Activated Carbon Fiber." Fibers and Polymers. 2015.16(3):543-9.

[4] Mahanim SMA, Wan Asma I, Rafidah J, Puad E, Shaharuddin H. "Production of Activated Carbon from Industrial Bamboo Wastes." Journal of Tropical Forest Science. 2011. 23(4):417-24.

[5] Tadda MA, Ahsan A, Shitu A, ElSergany M, Arunkumar T, Jose B, et al. "A Review on Activated Carbon: Process, Application and Prospects. Journal of Advanced Civil Engineering Practice and Research." 2016;2(1):7-13.

[6] Efeovbokhan VE, Alagbe EE, Odika B, Babalola R, Oladimeji TE, Abatan OG, et al. "Preparation And Characterization of Activated Carbon From Plantain Peel And Coconut Shell Using Biological Activators." Journal of Physics: Conference Series. 2019. 1378(3):1-17.

[7] Choirunnisa A, Wahyuningsih NE, Ginandjar P. "Efektivitas Variasi Ketebalan Arang Aktif Bambu dalam Menurunkan Kadar Kadmium (Cd) pada Larutan Pupuk Mengandung Kadmium." Jurnal Kesehatan Masyarakat (e-Journal). 2018. 6(6):17-23.

[8] Huang PH, Jhan JW, Cheng YM, Cheng HH. "Effects of Carbonization Parameters of Moso-Bamboo-Based Porous Charcoal on Capturing Carbon Dioxide." The Scientific World Journal. 2014;1-8.

[9] Prabarini, N and Okayadnya DG. "Penyisihan Logam Besi (Fe) pada Air Sumur dengan Karbon Aktif dari Tempurung Kemiri." Jurnal Ilmiah Teknik Lingkungan. 2014. 5(2):33-41.

[10] Erawati E and Ardiansyah F. "Effect of Activator Types and Active Carbon Size on the Making of Adsorbents from Sengon Wood Sawdust (Paraserianthes falcataria)." Jurnal Integrasi Proses. 2018. 7(2):58-66.

[11] Manurung M, Sahara E, Sihombing PS. "Pembuatan dan Karakterisasi Arang Aktif dari Bambu Apus (Gigantochloa apus) dengan aktivator H3PO4". Jurnal Kimia. 2019. 13(1):16-21.

[12] Laos LE, Selan A. "Pemanfaatan Kulit Singkong sebagai Bahan Baku Karbon Aktif." Jurnal Ilmu Pendidikan Fisika. 2016;1(1):32-6.

[13] Istighfarini SAE, Daud S, Edward H. "Pengaruh Massa dan Ukuran Partikel Adsorben Sabut Kelapa Terhadap Efisiensi Penyisihan Fe Pada Air Gambut." Jom FTEKNIK. 2007. 4(1):1-8.

[14] Maulinda L, Za N, Sari DN. "Pemanfaatan Kulit Singkong sebagai Bahan Baku Karbon Aktif." Jurnal Teknologi Kimia Unimal. 2015. 4(2):11-9.

[15] Nurull $\mathrm{F}$ and Ulfindrayani IF. "Sintesis dan Karakterisasi Karbon Aktif dari Limbah bambu Menggunakan Aktivator Asam Pospat ( $\left.\mathrm{H}_{3} \mathrm{PO}_{4}\right)$." Prosiding Seminar Nasional Sains dan Teknologi Terapan. 2019. 1(1):741-6.

[16] Bernal V, Giraldo L, Moreno-Piraján J. "Physicochemical Properties of Activated Carbon: Their Effect on the Adsorption of Pharmaceutical Compounds and Adsorbate-Adsorbent Interactions." Journal of Carbon Research. 2018. 4(62):1-20

[17] Yanti N, Anas M, Eso R. "Pengaruh Variasi Ukuran Bulir dan Waktu Aktivasi terhadap Daya Serap Arang Tandan Aren Pada Iodium ( $\mathrm{I}_{2}$ ) dan Metilen Blue (MB)." Jurnal Penelitian Pendidikan Fisika. 2020. 5(1):78-88.

[18] Nandiyanto ABD, Oktiani R, Ragadhita R. "How to Read and Interpret FTIR Spectroscope of Organic Material." Indonesian Journal of Science and Technology. 2019. 4(1):97-118. 
[19] Mentari VA and Maulina S. "Perbandingan Gugus Fungsi dan Morfologi Permukaan Karbon Aktif dari Pelepah Kelapa Sawit Menggunakan Aktivator Asam Fosfat $\left(\mathrm{H}_{3} \mathrm{PO}_{4}\right)$ dan Asam Nitrat $\left(\mathrm{HNO}_{3}\right)$." Talenta Conference Series: Science and Technology (ST). 2018. 1(2):204-8.

[20] Putri E and Anita S. "Potensi Arang Aktif Bambu Betung (Dendrocalamus Asper) Sebagai Adsorben Ion $\mathrm{Mn}^{2+}$ dan $\mathrm{NO}^{3-}$ dalam Air Sumur Bor Buruk Bakul." 2016. 3:203-42.

[21] SNI, 1995, SNI 06-3730-1995: Arang Aktif Teknis, Badan Standardisasi Nasional, Jakarta. 
